\title{
The role of formalization in the insertion of social indicators in the supply chain of the popular garnment sector
}

\author{
O papel da formalidade na inserção de indicadores sociais na \\ cadeia de suprimento do setor de confecção popular
}

\author{
Cristiane Mano do Nascimento ${ }^{1}$, Minelle E. Silva ${ }^{1}$ \\ ${ }^{1}$ Universidade de Fortaleza - UNIFOR, Programa de Pós-Graduação em Administração, Fortaleza, CE, Brasil. \\ E-mail: velmas.fashion@hotmail.com; minele.adm@gmail.com
}

How to cite: Nascimento, C. M., \& Silva, M. E. (2020). The role of formalization in the insertion of social indicators in the supply chain of the popular garnment sector. Gestão \& Produção, 27(4), e4708. https://doi.org/10.1590/0104-530X4708-20

\begin{abstract}
Under the supply chain sustainability debates and seeking to reduce the theoretical gap related to the social sustainability dimension, this research aims to analyze the relation between formalization and the insertion of social indicators in the supply chain of the popular garment sector in Fortaleza-CE. Using the case study strategy, 20 interviews were carried out with enterprises, direct suppliers and outsourced suppliers to cover the direct supply chain. Hence, were analyzed three categories - social responsibility, health and safety, and supplier development - and their 15 indicators. The results indicate that the formalization impacts on the insertion of social indicators, mainly in the category of health and safety. In addition, it was identified the possibility of informal work, even in the formalized companies, which demonstrates the need for a new look at this variable. With empirical demonstration, this study contributes to the study of social indicators in the supply chain and draws attention to informal labour relations in the local context.
\end{abstract}

Keywords: Social dimension; Supply chain; Formalization; Popular market.

Resumo: Considerando o tema sustentabilidade em cadeias de suprimento e buscando diminuir a lacuna teórica em torno do debate sobre a dimensão social da sustentabilidade, esta pesquisa tem como objetivo analisar a relação entre a formalidade e a inserção de indicadores sociais na cadeia de suprimento do setor de confecção popular em Fortaleza-CE. Por meio de um estudo de caso, foram realizadas 20 entrevistas com empresas focais, fornecedores diretos e terceirizados, o que abrange a cadeia direta de suprimento. Realizou-se análise de conteúdo a partir das categorias responsabilidade social, saúde e segurança e desenvolvimento de fornecedores e seus 15 respectivos indicadores. Os resultados indicam que a formalização impacta na inserção de indicadores sociais, principalmente na categoria de saúde e segurança. Além disso, identificou-se a possibilidade de existir trabalho informal, mesmo nas empresas formalizadas, o que demonstra a necessidade de um novo olhar para este indicador. Com demonstração empírica, essa pesquisa contribui com o estudo de indicadores sociais na cadeia de suprimento e chama atenção para relações informais de trabalho no contexto local.

Palavras-chave: Dimensão social; Cadeia de suprimento; Formalidade; Mercado popular.

Received Mar. 16, 2018 - Accepted June 28, 2018

Financial support: None.

This is an Open Access article distributed under the terms of the Creative Commons Attribution License, which permits unrestricted use, distribution, and reproduction in any medium, provided the original work is properly cited. 


\section{Introduction}

Discussions on sustainability have intensified in the business environment and reflect on the role companies play in society. This is possible through successive pressures for more transparent, human and ethical actions in business (Van Marrewijk, 2003). These pressures have become part of organizations' routine (Campos et al., 2014). However, organizations find it difficult to make an association between their managerial practices and their discourse, regarding the interpretation and definition of sustainability (Claro et al., 2008).

According to Claro et al. (2008), the so-called sustainable development emerged in 1987, when the World Commission on Environment and Development of the United Nations released the report "Our Common Future" (i.e. Brundtland report). This report considers that sustainable development must meet the needs of present generations without compromising the needs of future generations (WCED, 1987). This definition makes clear one of the principles of sustainability, the long-term vision, since the interests of future generations should be analyzed (Claro \& Claro, 2004).

The inclusion of sustainability in organizations can happen, according to Markley \& Davis (2007), by the coordination of partnerships and relationships. Most companies are part of at least one supply chain (Samaranayake, 2005). Thus, to incorporate sustainability it is necessary to look beyond intraorganizational boundaries and extend to the interorganizational boundaries along their supply chains (Vachon \& Klassen, 2008; Zacharia et al., 2011). Therefore, sustainability has become one of the challenges for organizations, since there is a need to incorporate the dimensions of sustainability in a balanced way in its operations (Carter \& Rogers, 2008; Seuring et al., 2008; Seuring \& Müller, 2008; Seuring, 2013).

To contribute to discussions that emphasize the social issue and its practices, both in theory and empirical lens, the social dimension is understood as the set of indicators that can be observed in a supply chain regarding to sustainability. Thus, such actions are related to the contribution companies have in society at the intra- and inter-organizational levels. The social dimension is not only synonymous of ethics among members of a supply chain, but includes practices such as: philanthropy, community work, security, human rights, good working conditions, etc. (Markley \& Davis, 2007). In addition, this discussion highlights a cultural-historical background that influence in the process of understanding how organizations interact to deliver their product/service (Alves \& Silva, 2017).

In the literature, there are several debates about which elements can be used on managing social indicators in the supply chain (Silva \& Nascimento, 2015; Yawar \& Seuring, 2017); however it is still with little consistency. In Brazil, the concern with social issues has been intensified, mainly after several scandals that happened in the garment sector of the country. According to Alves \& Silva (2017), it is increasingly necessary to look at elements such as slave labor, child labor and respect for human rights. However, beyond this question, it is necessary to observe the companies' formalization in the sector, since the outsourcing relationships are intensive and can often arise elements that affect the social indicators.

As presented by Heleno (2013), one main characteristic of the garment sector is the influence received by the fashion industry, which following the seasons, determines patterns and behaves in a very flexible way. Thus, workers in this sector can be subjected to informal work, since labor rights are often not considered. In the same perspective, Lima (1999) states that precarious working conditions may arise, since sewing is considered easy to learn, disqualified and consequently poorly paid. These 
elements demonstrate the need to study this sector that has relevance in the market. Despite that, there are still incipient definitions in the literature once (in)formality is a complex theme (Vargas, 2016).

From the arguments presented so far and the research gap regarding social issues in the garment sector (Köksal et al., 2017), mostly in emerging countries, this paper aims to analyse the relation between formalization and the insertion of social indicators in the supply chain in the garment sector in Fortaleza-CE. From this perspective, it is assumed that the formalization can facilitate the insertion of social indicators, since informality has some clear characteristics in relation to what is defined as decent work (Vargas, 2016).

This research is relevant by considering the emergence of studies on supply chain sustainability and by the recognition of the garment sector based on their specificities, such as outsourcing activities (Dicken, 2007). Furthermore, Yawar \& Seuring (2017) point out that there are a number of issues related to the social dimension that need attention of both professionals and researchers. The sector was selected following its economic importance, since in Brazil the annual reveneus of the sector is US $\$ 39.3$ billion, with investment in the sector of US $\$ 869$ million and average production is 6.7 billion (ABIT, 2017).

To better understanding of the study, it is divided into five sections beyond this introductory one. The second section presents the theoretical basis used for supply chain sustainability (SCS) and social indicators for SCS. In the third section, are the methodological procedures that precede the analysis of the results explained in the fourth section. The fifth section presents the research discussions and, finally, the final considerations are presented, highlighting the contributions of the research.

\section{Theoretical background}

The present section includes the theoretical approach, highlighting the supply chain sustainability (SCS) and, in particular, the social indicators for SCS.

\subsection{Supply chain sustainability: an overview}

Sustainability has emerged as an important issue for organizations, society and the planet, by the increasing concern with the finite resources (Andersen \& Skjoett-Larsen, 2009; Markley \& Davis, 2007). Globalization and the rapid development of Third World economies have significantly increased the erosion of the earth's natural resources. From the flow of information and the greater transparency that allowed a quicker perception of what is happening around the world with companies, their suppliers and customers (Meixell \& Luoma, 2015).

Therefore, it is necessary to study the supply chains, since the actors belonging to this interorganizational relationship are not mere supporters to new sustainability practices, but actors who must act actively (Silva \& Nascimento, 2016). The need to incorporate new sustainability responsibilities is becoming increasingly as a motivating factor for building relationships that lead to the continuity and improvement of relationships in the supply chain (Silva et al., 2016). Thus, the management of relations among actors in the supply chain becomes fundamental (Chen et al., 2009).

According to Alves \& Silva (2017), thinking about how repositioning the results of the companies by considering the environment and the society was possible to emerge 
the approach between sustainability and supply chain strategy. For Abdala \& Barbieri (2014), the main diference between green supply chain management (GSCM) and Sustainable Supply Chain Management (SSCM) is regarding the focus on social issues throughou the supply chain. For the current research, the focus is on supply chain sustainability (SCS) since there are some theoretical inconsistences in the use of SSCM. Also this is used since management is embeded in the relationship between both topics. It is worth noting that sustainability is both process and target, thus nothing can be considered sustainable at the moment.

SCS receive more attention from 2008 after several publications such as: Carter \& Rogers (2008) e Seuring \& Müller (2008), bringing a greater base on operations management and Pagell \& Wu (2009) more related to sustainability as a whole. However, the debate has been increasing and the number of publications has grown rapidly (Gold, 2016). Despite the few discussions in Brazil that consider sustainability along the supply chain, several authors (Abdala \& Barbieri, 2014; Carvalho \& Barbieri, 2013; Neutzling, 2016; Silva \& Nascimento, 2015; Alves \& Silva, 2017) are seeking to develop research in this context and giving greater emphasis to social aspects. In this way, discussions on social issues are arising as an essential element to achieve an effective understanding of sustainability.

For instance, there are problems related to employment relationships that can be observed in the same supply chain (Leão \& Vasconcellos, 2015), which demonstrate the need for more emphasis on social issues. In this way, formalization issues emerge as essential to the SCS debate. According to Mendes \& Campos (2004), under the supply chain context, there is a need for more relations between the formal and informal sectors of the economy. "Informal work does not exist randomly; it forms the formal supply chain, understood here as the set of activities that are progressively articulated, from the basic inputs to the product, distribution and commercialization, such as links of a chain" (Mendes \& Campos, 2004, p. 213). Thus, for Leão \& Vasconcellos (2015), the precarious conditions regarding health and safety in informal work demonstrate the limits of the intervention of the oversight agencies, which cannot observe at the productive chain as a whole. Such questions raise the need to reflect and research on formal and social elements in the supply chain.

\subsection{Social indicators for supply chain sustainability}

The social dimension of sustainability consists of human-related entrepreneurial skills and experiences that extend both to the internal and external environment of the company (Almeida, 2002). For Silva \& Nascimento (2015, p. 483), social sustainability is "[...] a set of 'human' elements geared towards total sustainability". In a complementary way, Claro \& Claro (2004) indicate that the social dimension consists in characteristics of human beings, which support social welfare, encompassing the internal and external environment of the company. Thus, the social debate goes beyond the limit of the technique and begins to consider the existence of intangible elements in the management of the supply chain.

There are several ways to study social issues in the literature. One of them is presented by Glavič \& Lukman (2007) to identify some principles of sustainability. According to the authors, for social sustainability to be achieved, the following principles must be observed: social responsibility, health and safety, polluter pays principle and reports to stakeholders. By considering that the last two principles do not have direct influence in the context studied here, it is assumed as macro social principles: social 
responsibility and health and safety, which are part of the research carried out. In a complementary way, we searched the literature about the supply chain and the garment sector.

Focused on supply chains, Yawar \& Seuring (2017) found working conditions (health and safety), human rights, disabled/marginalised people inclusion, minority development and gender, as social problems that must be considered. Ashby et al. (2012) also developed a literature review focused on the social and environmental dimensions of sustainability, in which found as more clearly defined categories of social dimension used through supply chains: health and safety, social equity, prevention of exclusion and supplier relationship. And Köksal et al. (2017), defined social responsibility and supplier development as the main social issues to study the social dimension of sustainability in supply chains.

To cover different levels of discussion on the social issues in supply chains, from the review of the literature of these authors, Table 1 consolidates the social indicators for the present research, according to the categories: social responsibility, health and safety, and supplier development throughout the supply chain. Thus, these indicators focused on the social issue can be used to analyse different sectors, depending on their specificities.

Table 1. Classification of social issues from a supply chain perspective.

\begin{tabular}{|c|c|}
\hline Social indicators & Description \\
\hline \multicolumn{2}{|l|}{ Social responsibility } \\
\hline Slavery work & $\begin{array}{l}\text { The company should not engage with or support the practice of } \\
\text { using forced work }\end{array}$ \\
\hline Child work & $\begin{array}{l}\text { The company should not engage with or support the practice of } \\
\text { using child work }\end{array}$ \\
\hline Ethical behaviour & $\begin{array}{l}\text { The company must contribute to economic development, aiming to } \\
\text { increase the environmental quality and quality of life of society. This } \\
\text { indicator is taken as a self-declaration of actions carried out in this sense. }\end{array}$ \\
\hline Community work & Refers to philanthropic activities and works with local communities \\
\hline Unfair wages & $\begin{array}{l}\text { The company should not engage with or support, breach rules set by } \\
\text { law, paying unfair wages lower than permitted salary. }\end{array}$ \\
\hline Minority inclusion & $\begin{array}{l}\text { It is the development of populations that are considered as } \\
\text { minorities, in terms of population by their religion, race, ethnicity, as } \\
\text { well as due to physical disabilities. }\end{array}$ \\
\hline Gender & $\begin{array}{l}\text { Equal treatment of women and transgender people, taking into account } \\
\text { their special needs and the attribution of equal rights in the workplace. }\end{array}$ \\
\hline $\begin{array}{l}\text { Marginalised people } \\
\text { inclusion }\end{array}$ & Population living below the poverty line is considered marginal. \\
\hline \multicolumn{2}{|l|}{ Health and Safety } \\
\hline Work schedule & $\begin{array}{l}\text { It is compliance with applicable laws and industry standard on } \\
\text { working hours and breaks }\end{array}$ \\
\hline Working conditions & $\begin{array}{l}\text { The company shall provide a safe, healthy and enjoyable working } \\
\text { environment by taking appropriate measures for the prevention of } \\
\text { occupational accidents and diseases associated with the } \\
\text { performance of productive activities }\end{array}$ \\
\hline Awards & $\begin{array}{l}\text { Award practice strategy for employees in the context of other } \\
\text { organization recognition practices. }\end{array}$ \\
\hline \multicolumn{2}{|c|}{ Supplier development } \\
\hline Type of Relationship & $\begin{array}{l}\text { Collaborative relationships of external stakeholders such as NGOs, } \\
\text { which require companies to better manage social issues and internal }\end{array}$ \\
\hline
\end{tabular}


Table 1. Continued...

The role of formalization in the insertion of social indicators...

\begin{tabular}{ll}
\hline & $\begin{array}{l}\text { stakeholders such as top management, who follow the performance } \\
\text { objective, addressing social issues in supply chains. }\end{array}$ \\
\hline Trust & $\begin{array}{l}\text { The trust relationship between buyers and suppliers determines the } \\
\text { degree to which social issues are managed in supply chains. Value } \\
\text { is created along the supply chain if the relationship between buyers } \\
\text { and suppliers thrives on trust and commitment. }\end{array}$ \\
\hline Supplier assessment & $\begin{array}{l}\text { It assesses how the supplier deals with social issues in supply } \\
\text { chains to meet the demands and concerns of stakeholders and how } \\
\text { it creates actions to overcome problems involving the social } \\
\text { dimension. }\end{array}$ \\
\hline Supplier selection & $\begin{array}{l}\text { Refers to the social criteria used by the company in selecting its } \\
\text { suppliers. }\end{array}$ \\
\hline
\end{tabular}

Source: Based on Ashby et al. (2012), Köksal et al. (2017) and Yawar \& Seuring (2017).

Based on the elements presented in the previous table, it is understood that for a company to perform well in relation to the social dimension it is necessary to commit itself to good practices of employment and work, improving its work places, being involved in social projects into local communities and communicate with the communities involved about the consequences of their activities and products, i.e. the impacts of their activities on the environment and society as a whole (Kanji \& Chopra, 2010). Under this context the focus here is to debate about social indicators toward SCS. For this research, the emphasis on small and medium enterprises (SMEs) represents better the local economy.

Ciliberti et al. (2008) argue that research into the practices adopted and the difficulties experienced by SMEs can be very useful for managers who are willing to deal with socio-environmental issues along the supply chain, especially in emerging countries. According to Hamann et al. (2005), SMEs operating in developing countries face a number of challenges, for example lack of orientation and skills transfer, communication gaps, lack of development opportunities, infrastructure scarcity, low savings rates and financial services. These elements can be explained by the size of the companies (Lepoutre \& Heene, 2006). In addition, SMEs generally have a small bargaining power; larger firms have more power to stimulate socially responsible behavior among their partners in the supply chain (Lepoutre \& Heene, 2006).

This aspect becomes even clearer in the context of garment. According to Neves \& Pedrosa (2007), sewing and finishing when outsourced are carried out by so-called facções. In the garment industry, facções refers to the informal and precarious work of domestic seamstresses. Araújo \& Amorim (2016) carried out a research in the region of Campinas (São Paulo) regarding subcontracting networks and home-based work in the garment sector, and verified that the seamstresses at home are totally subordinated to the conditions, deadlines, payment methods and taxes, but in a relation precarious work, established informally to escape regulation and legal charges. Precarization is a central process influenced by the new technological and economic requirements of the modern capitalism (Castel, 1998).

Hirata \& Préteceille (2002), when analyzing studies and research in France, drew attention to the diversity and complexity of problems arising from flexibility and precariousness of work, in addition to the weakening of employment. For the authors, the double transformation of work - both in relation to the content of the activity and the forms of employment - demonstrates the importance of analyzing the organization of work and the labor market. According to Leão \& Vasconcellos (2015), from the concept of supply chain and social responsibility discourse, informal workers linked to industrial 
activities as suppliers, service providers, distributors and consumers "[...] should be considered as 'partners' and 'strategic stakeholders', also in critical and vulnerable areas of current work informality, particularly in the field of health and safety at work" (Mendes \& Campos, 2004, p. 221).

Informality holds certain unique characteristics (Vargas, 2016) that may be related to labor law. However, when it comes to social issues, we seek to debate elements that go beyond the legal issue. For instance, social responsibility may be related legality, but the focus is on the ethical point of view. Thus, considering the elements presented that involve formalization of work and the need to study the social dimension of sustainability, the present research seeks to understand relations still unclear in the literature and that can demonstrate a strong contribution to understand contexts. Following are information about the research.

\section{Method}

To identify the relationship between formalization and the insertion of social practices in the supply chain of the popular market of Fortaleza-CE, this research is based on a qualitative exploratory approach. According to Goldenberg (2004, p. 53), "[...] qualitative data consists of detailed descriptions of situations with the aim of understanding individuals on their own terms". A case study was carried out, because this method brings an empirical investigation that analyzes a contemporary phenomenon within its real life context, especially when the boundaries between phenomenon and context are not well defined (Yin, 2015).

To meet the selected research method, interviews were conducted with different members of the supply chain, focusing on recognizing actions in specific contexts (Gaskell, 2002). The data collection was carried out from June to November of 2017 with interviews and technical visits to the production sites. The interviews followed the semi-structured script (Appendix A), however additional questions were asked during the contact with the respondents. Twenty interviews with different actors of the chain were carried out, among them: 13 focal companies that are responsible for producing and/or selling the pieces produced in the city, two suppliers (one fabric and one assessory) that can be considered suppliers of raw material, and five service providers, called facções (which are outsourced). To better identify each respondent, Table 2 presents individual information for each.

Table 2. Information of the interviews.

\begin{tabular}{|c|c|c|c|c|c|}
\hline Companies & Code & $\begin{array}{l}\text { Classification } \\
\text { formal/informal }\end{array}$ & $\begin{array}{c}\text { Time of } \\
\text { operation at } \\
\text { José Avelino }\end{array}$ & $\begin{array}{l}\text { Quantity of } \\
\text { employees }\end{array}$ & $\begin{array}{l}\text { Interview } \\
\text { time }\end{array}$ \\
\hline Company 1 & $\mathrm{E} 1$ & Formal & 10 years & 7 & $35 \mathrm{~min}$ \\
\hline Company 2 & $\mathrm{E} 2$ & Informal & 10 years & 0 & $41 \mathrm{~min}$ \\
\hline Company 3 & E3 & Formal & 10 years & 5 & $50 \mathrm{~min}$ \\
\hline Company 4 & E4 & Informal & 7 years & 3 & $25 \min$ \\
\hline Company 5 & E5 & Formal & 15 years & 1 & $37 \mathrm{~min}$ \\
\hline Company 6 & E6 & Formal & 17 years & 2 & $26 \min$ \\
\hline Company 7 & E7 & Formal & 7 years & 3 & $45 \mathrm{~min}$ \\
\hline Company 8 & E8 & Formal & 4 years & 4 & $35 \mathrm{~min}$ \\
\hline Company 9 & E9 & Formal & 18 years & 4 & $36 \min$ \\
\hline
\end{tabular}


Table 2. Continued...

The role of formalization in the insertion of social indicators...

\begin{tabular}{cccccc}
\hline Companies & Code & $\begin{array}{c}\text { Classification } \\
\text { formal/informal }\end{array}$ & $\begin{array}{c}\text { Time of } \\
\text { operation at } \\
\text { José Avelino }\end{array}$ & $\begin{array}{c}\text { Quantity of } \\
\text { employees }\end{array}$ & $\begin{array}{c}\text { Interview } \\
\text { time }\end{array}$ \\
\hline Company 10 & E10 & Formal & 3 years & 8 & 22 min \\
\hline Company 11 & E11 & Formal & 2,5 years & 30 & 51 min \\
\hline Company 12 & E12 & Formal & 8 years & 10 & 47 min \\
\hline Company 13 & E13 & Formal & 4 years & 14 & 38 min \\
\hline Supplier 1 & FORN1 & Formal & 7 years & 6 & 35 min \\
\hline Supplier 2 & FORN2 & Formal & 20 years & 70 & 41 min \\
\hline Facção 1 & F1 & Informal & 15 years & 15 & 25 min \\
\hline Facção 2 & F2 & Informal & 13 years & 2 & 27 min \\
\hline Facção 3 & F3 & Informal & 20 years & 1 & 36 min \\
\hline Facção 4 & F4 & Informal & 1 year & 1 & 25 min \\
\hline Facção 5 & F5 & Informal & 3 years & 2 & 33 min \\
\hline
\end{tabular}

As shown in the table, we searched for companies with different profiles and characteristics that represent the local context. The interviews were recorded and transcribed to ensure the reliability of the study. the criterion of selection of respondents considered the need for action by the focal companies at the José Avelino Fashion Center, located in Fortaleza, the fifth largest Brazilian capital (IBGE, 2016). Nowadays, the fashion center has about 32 enterprises, with 10,200 points of sales, in which there are 9 malls and 23 warehouses, where more than 20 thousand people work, also counting on parking to receive 92 buses, running daily, generating occupation and income for about 100 thousand person.

Based on the collected data, a content analysis was performed (Bardin, 2011) following the deductive logic, "[...] which stems from the analyst's questioning in the face of an object of study, using a system of theoretical-analytical concepts whose articulation allows us to formulate the rules of inference" (Guerra, 2006, p. 62). In this analysis the categories were determined a priori (Guerra, 2006), according to the literature review. Thus, the 15 selected indicators were used in the categories Social Responsibility, Health and Safety and Supplier Development (Ashby et al., 2012; Köksal et al., 2017; Yawar \& Seuring, 2017). The selected categories were used both to develop the initial interview script and to facilitate the data interpretation process. The internal validation of the selected data was used as the central quality criterion of the research, following the arguments of Yin (2015).

\section{Results}

In this section, the analyzes performed with the obtained results are exposed. For a more detailed understanding of the supply chain studied and the relationships between the respective links, first information on the supply chain of the José Avelino Fashion Center is presented. Then, the results focused on the fulfilment of the research objective are described. 


\subsection{The supply chain structure of the José Avelino Fashion Center}

The garment industry in the state of Ceará currently ranks fifth in the ranking of Brazilian industry (ABIT, 2017). The positioning of the popular market is to create fast fashion, which has a significant impact on social and environmental sustainability. Brazil has one of the most complete garment supply chain in the world, since produce everything from fibers to clothing (ABIT, 2017). However, according to this association, due to the low productivity of companies, the textile sector ends up in outsourced manufacturing processes.

The search for outsourcing is a way found by companies to reduce their production costs, thus increasing problems with labour laws, a greater proliferation of informality, and bringing losses to the chain as a whole (Alves \& Silva, 2017). The textile and apparel supply chain sometimes overlaps and, to better clarify the context of the José Avelino Fashion Center, the research sought to identify the existing structure. As can be seen in Figure 1

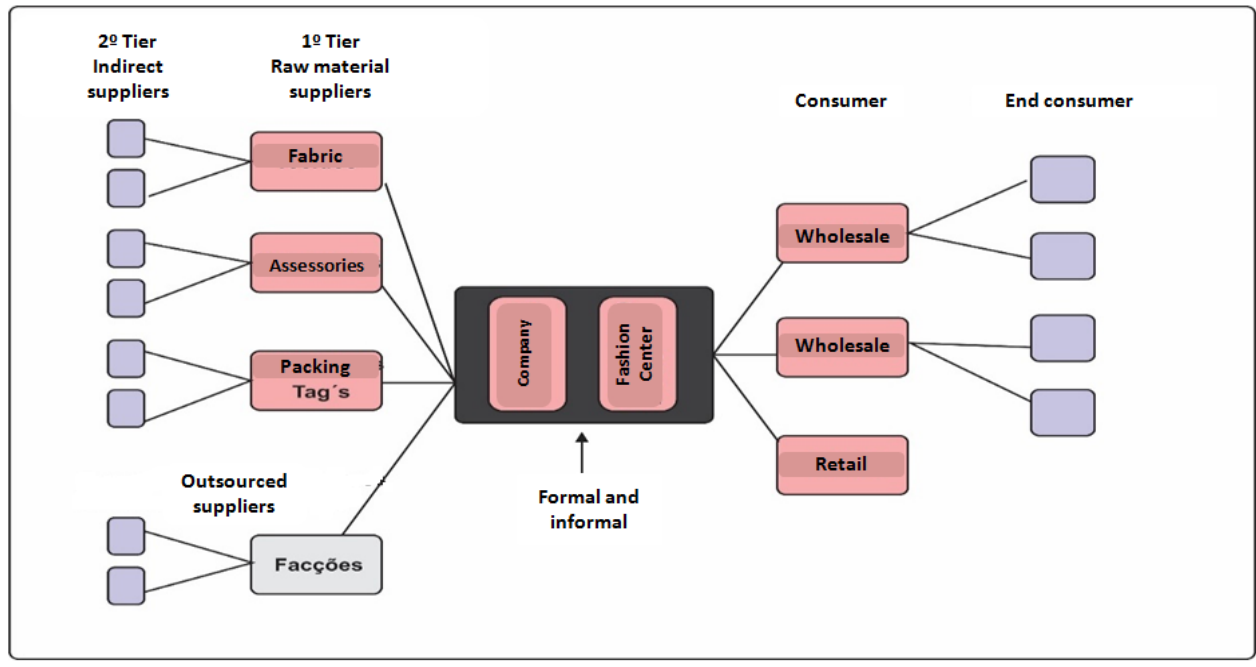

Figure 1. Local garment supply chain Source: Own data (2017).

The links upstream of the supply chain are the first tier suppliers in the chain: suppliers of raw materials (fabrics, accessories, packaging and tag's). It is worth mentioning that the fabric suppliers of this chain are not textile industries, that is, they already buy the finished fabric and pass it on to the manufacturers of the José Avelino Fashion Center. According to the data, most suppliers import these fabrics from China and are located in Fortaleza, that is, they are regional. In relation to suppliers of goods (blades, buttons, ornaments) most companies buy in Fortaleza. As indicated in the figure, there are also service providers (facções - i.e. outsourced), related to the sewing and finishing of the pieces (parts cleaning, buttonhole, buttons, tag placement, and packaging). There is outsourcing about several steps of the production since the companies studied do not produce their parts inside the factory, all outsource the sewing service.

In the downstream link of the companies are the customers: wholesale (sackcloth), atacadão (stores and magazines) and retail. Wholesale customers - also known as baggers (i.e. sacoleiros) - are mostly from other states, and may also be from Fortaleza, 
or from the interior of Ceará. These customers buy to resell in small neighborhood stores or at the door of end consumers. The atacadão represents large stores and magazines, which mostly buy through the direct representatives of the factory, in large quantities, and put their own labels (brand name). These customers serve end consumers generally in large stores in malls. The retail is composed by the customers who buy of a piece for its use or to give a gift, are mostly clients of Fortaleza or tourists. All these actors are influencing the insertion of social indicators along the supply chain, since changes in the classification of companies from informal to formal are taking place. In the present research, the clients were not interviewed, only the focal companies and suppliers that represents the direct supply chain.

\subsection{Social indicators at José Avelino Fashion Center}

As previously mentioned, the fashion center stores are organized in malls and warehouses. The companies located in the warehouses, in general, are considered as informal, and at the moment of the research there is no obligation required by the state governments, and the municipality to own CNPJ (National Register of Legal Entities). Of the three companies located in the warehouses, only the company (E2) does not yet have CNPJ, but according to the manager of the company, the accountant was already providing an MEI (Individual Micro Entrepreneur). After the interviews with the companies, it was verified that the companies located in the warehouses, even without being required for having an open company (registration and CNPJ) are formalized (E7 and E9) or in process (E2). This shows that the focal companies in the warehouses also have a formalization in relation to the malls.

All companies studied in shopping malls (E1, E3, E4, E5, E6, E8, E10, E11 E12 and $E 13)$ have registered in the commercial board and according to their managers are active, except for company E4, who answered: "I have the company, but at the moment ... it is not currently active". There is in the speech of the manager of the company E4 the registration of CNPJ, but for some reason is not operating. The results showed that there is a requirement of the state government and the city hall, that the companies located in the malls may be formalized, having to be properly regularized and acting in their focus. Thus, initially the idea is that formalization is an element that has been increasingly valued in the context studied.

Therefore, for the present research, all those studied who have employees within their companies without a CTPS (Work and Social Security Document) are considered as informal groups regardless of whether their companies are registered (i.e. have CNPJ); and formal group all those studied who have employees within their companies with CTPS. For this, Tables 3 and 4 present the classification performed in this research and the division of the two groups (formal and informal) among those studied. This proposal refers to debate the role of formality, which have official groups, but does not exist in the daily reality of companies, which need to analyse alternatives to remain within the market, even if using informality. 
Table 3. Group of companies and suppliers that have formal work.

\begin{tabular}{cl}
\hline Companies & \multicolumn{1}{c}{ Formal Group } \\
\hline E1 & All my employees are formal \\
\hline E6 & $\begin{array}{l}\text { I got already twenty employees, but I was firing them, and right now I'm alone } \\
\text { with two people. One girl there in the store, one at Beco da Poeira and a } \\
\text { person doing the finishing there at home and alone. This all wallet signed. }\end{array}$ \\
\hline E7 & All formal [referring to your employees] \\
\hline E11 & $\begin{array}{l}\text { Yes, everyone is formal } \\
\text { in the company. Twelve here, inmates. Outside, the saleswomen ... Around a } \\
\text { total of thirty employees between: models, stylists ... They are all formal. }\end{array}$ \\
\hline E13 & $\begin{array}{l}\text { Here in the factory we have fourteen direct, fourteen! And indirectly we have } \\
\text { over forty people working. They are signed. }\end{array}$ \\
\hline Forn 1 & $\begin{array}{l}\text { All formal [referring to your employees] } \\
\text { Forn2 }\end{array}$ \\
\hline
\end{tabular}

Source: Own data (2017).

The statements presented in the above table confirm the definition of the companies presented there as formal, since they have all their employees covered by all labor rights. Following are the companies that, even though they have a formality with government entities, present informal work, since for the development of their activities, there are unregistered employees. According to Vargas (2016), there is a clear point between informal work and the informal economy, something that is very clear in the research context.

Table 4. Group of companies and suppliers with informal work.

\begin{tabular}{|c|c|}
\hline $\begin{array}{l}\text { Companies/ } \\
\text { Facções }\end{array}$ & Informal Group \\
\hline E2 & $\begin{array}{l}\text { No. No. Because as I told you we are not with the firm yet registered the guy } \\
\text { is still registering, the accountant! Then when he gets it I'll sign my wallet with } \\
\text { my grandson and my daughter }\end{array}$ \\
\hline E3 & Only two that is not because them were hired now \\
\hline E4 & No. There is not \\
\hline E5 & $\begin{array}{l}\text { No. Today I have one employee with wallet signed. However, I still have my } \\
\text { factory and there are some people without wallet signed }\end{array}$ \\
\hline E8 & $\begin{array}{l}\text { No. They are not all formal. Actually, there's a formal one, one is ... By the way, } \\
\text { two! One is already registering, the other I will register and the forth I cannot ... I } \\
\text { work with him in a different way, as if he were a freelance. That's Bruno. }\end{array}$ \\
\hline E10 & $\begin{array}{l}\text { It's because I do not need ... Yeah. When I need it. It's by production. It's not even } \\
\text { a day job, it's production. She has to make me twenty new pieces a month. And I } \\
\text { paid individually for these pieces. If she spends all morning here and only makes } \\
\text { a piece, I pay for a piece. It is not daily. However, my stylist is already per day. }\end{array}$ \\
\hline F1 & $\begin{array}{l}\text { It's ... It's complicated because I .... If I formalize I have to close the doors. } \\
\text { Because lately I'm not taking it to me, and they know it. Because at home I } \\
\text { leave everything very comfortable, they know everything from how much I get } \\
\text { a piece, how many pieces did we produce, right? }\end{array}$ \\
\hline $\mathbf{F 2}$ & No, I've never been interested in opening ... Not to register. \\
\hline $\mathbf{F 3}$ & No. No [referring to non-existence of registered employees] \\
\hline F4 & No [referring to non-existence of registered employees] \\
\hline F5 & No [referring to non-existence of registered employees] \\
\hline
\end{tabular}

Source: Own data (2017). 
As can be seen in Table 4, companies E3, E4, E5 and E8 have CNPJ, however they have informal work within their factories. For the facções, it was not found, within the context of the research, none with CNPJ and, consequently, none of its employees have a formal contract. This fact demonstrates that outsourced work still has a strong impact on the economic dynamics of a locality. This is done centrally by the lack of legitimacy of informal companies with society, as to paying taxes and keeping up with legal obligations. For suppliers, no informality was found.

After this classification, in which all the companies interviewed are reorganized according to their daily practice and not only following the requested formalization criterion, the focus was to analyze the existence of social indicators in the garment chain studied. For a better understanding of the practices carried out by this supply chain, the analysis carried out according to each of the groups organized here (formal and informal group) follows.

\subsubsection{Analysis of social indicators for the formal group}

As can be seen in Table 5, the excerpts presented represent the way social indicators are being developed in the sector by the formal group.

Table 5. Classification of social issues from the formal group perspective.

\begin{tabular}{|c|c|}
\hline Social Indicators & Quotes \\
\hline \multicolumn{2}{|l|}{ Social Responsibility } \\
\hline Slavery work & I've heard at the news [slavery work] (E1). \\
\hline Child work & No, I've never heard of child work from manufacturers! (FORN 1) \\
\hline Ethical behaviour & $\begin{array}{l}\text { We did not have it like this... Government incentive and we really } \\
\text { rehabbed, a lot here from the factory... They are people: Ex-addicts, } \\
\text { ex-drug addicts, it's a good slice of our employees and they even learn } \\
\text { in practice, they will... One teaching to the other who is entering and } \\
\text { the starting point of all of them was my husband himself (E13). }\end{array}$ \\
\hline Community work & I donate to the Cancer Institute! (E9). \\
\hline Unfair wages & Yes, we are paying the salary above what is required (E13). \\
\hline Minority inclusion & $\begin{array}{l}\text { There is no problem. Even the company is very mixed regarding } \\
\text { religion, right? We have here protestants, Catholics, various types. } \\
\text { And that's not even in our register to ask, right? (FORN2). } \\
\text { No, in reality, I outsource } 90 \% \text { right? So here, I do not think I have } \\
\text { conditions to hire these people (E9). }\end{array}$ \\
\hline Gender & $\begin{array}{l}\text { No way! I work with them here! I have stylists, I have dressmakers } \\
\text { who are man and I have no problem at all (E11). }\end{array}$ \\
\hline $\begin{array}{l}\text { Marginalised people } \\
\text { inclusion }\end{array}$ & $\begin{array}{l}\text { Most of the painting and stamping sectors have them. It is precisely } \\
\text { because of this social project that they go hand in hand. What is } \\
\text { reintegration into society. That's the part. The guys working with } \\
\text { Calandro (big machine of stamping fabric), they were prisoners, one } \\
\text { was robber, today is not anymore. Today the right arm of her } \\
\text { husband, more trustworthy to save money for her husband, in high } \\
\text { values, he was a thief, he plucked a house (E13). }\end{array}$ \\
\hline \multicolumn{2}{|l|}{ Health and safety } \\
\hline Work schedule & $\begin{array}{l}\text { From eight to five in the afternoon. And on Saturday from eight to } \\
\text { noon. But always leave at eleven. [referring to working schedule] } \\
\text { (FORN1).. }\end{array}$ \\
\hline
\end{tabular}


Table 5. Continued...

\begin{tabular}{ll}
\multicolumn{1}{c}{ Social Indicators } & \multicolumn{1}{c}{ Quotes } \\
\hline Working conditions & $\begin{array}{l}\text { The ones I have contact offer working conditions but what I used to } \\
\text { relate had problems before. There were some that explored too } \\
\text { much (FORN2). }\end{array}$ \\
\hline Awards & $\begin{array}{l}\text { Awards. If the employee do not miss a workday, we provide it! } \\
\text { Person who does not lack, it has an award, the person who has } \\
\text { production has a award. Overtime payment... All correct. (E11). }\end{array}$ \\
\hline Supplier Development & $\begin{array}{l}\text { We travel to visit some suppliers, we go to the suppliers ... We often } \\
\text { go to do the shopping properly ... From time to time we even do } \\
\text { these purchases. You're having this closer relationship with them } \\
\text { (E13). }\end{array}$ \\
\hline Trust & $\begin{array}{l}\text { We trust, distrusting because it has to be with the seamstress ... } \\
\text { We need to have close look [referring to outsourced] (E6). }\end{array}$ \\
\hline Supplier assessment & $\begin{array}{l}\text { No. I visit, but only they are in São Paulo, but they want us to go with } \\
\text { them to China to say the product we want to give them a tip and I } \\
\text { never went. But for Sao Paulo I always go. To see the market right? } \\
\text { It's more about research (FORN1). }\end{array}$ \\
\hline $\begin{array}{l}\text { Several suppliers, from whom to bring more differential. Nowadays, } \\
\text { we are practically like this, choosing who brings some differentiated } \\
\text { because the customer only wants differentiated right? (FORN1) }\end{array}$ \\
\hline $\begin{array}{l}\text { Supplier selection } \\
\text { bource: Own data (2017). }\end{array}$
\end{tabular}

Source: Own data (2017).

It can be seen in the speech of the respondents of the formal group in the category of Social Responsibility, that for the indicators of slavery work and child work there are no cases in the city, which is positive. It is worth mentioning that this is a very delicate subject and that at certain moments there was discomfort in answering such question, but since there was a pattern among the answers it is believed that this is an indicator that is not observed in Fortaleza, at least in the group that was studied. All the companies in this group presented ethical behavior, in the economic development requirement, because for them they generate employment and income. In relation to philanthropic actions and community work, the only finding was the making of donations. In relation to paying low salaries to employees all companies claim to pay fair wages within the legislation.

Regarding the inclusion of disabled people, all companies responded that they did not have disabled people in their staff. Concerning the hiring of minorities, all companies responded that they would have no problem hiring people of other religions, races or ethnicities. Thus, it would require a more in-depth discussion on why there are no problems, but in some cases these are not hired. About gender, the companies said they treated all the same in their companies, and did not have problems in hiring males and homosexuals. And as for the inclusion of marginalized people, most companies said they did not have marginalized people in their staff except E13 who has a social project.

In the Health and Safety category, the companies affirmed that they comply with the 44 weekly hours required by the legislation and the unions responsible for the working hours of their employees. Regarding the working conditions, all the companies responded to offer good working conditions to their employees. In the award indicator, only companies E1 and FORN2, do not offer any premium to their employees, other companies for this group have awards. In this case, it is understood that there is compliance with labor legislation, but also the appreciation of the human factor, something that directly affects the social dimension. 
For the Suppliers Development category, the formal group maintains long-term relationships, but does not or does not receive any type of training, with respect to social issues. This fact demonstrates an emphasis on in-house activities that do not seem to be widespread throughout the supply chain. Regarding to trust, this group had lower levels of confidence regarding the facções, i.e. the formalization does not necessarily demonstrate the creation of trust, which could be a more identified element. For this group, there was no identification of supplier assessment, and did not show any criteria for the Selection of Suppliers in relation to social risks. In general, it is perceived that the formal group presents some actions, but still limited in the interaction between actors.

\subsubsection{Analysis of social indicators for the informal group}

As can be seen in Table 6, the excerpts presented represent the way social indicators are being developed in the sector by the informal group.

Table 6. Classification of social issues from the informal group perspective.

\begin{tabular}{|c|c|}
\hline Social Indicators & Quotes \\
\hline \multicolumn{2}{|c|}{ Social Responsibility } \\
\hline Slavery work & We listen sporadically, but that there at home never had anything (E5) \\
\hline Child work & $\begin{array}{l}\text { No. I've never heard of it; neither. Because so, the facção is always } \\
\text { woman, husband and children that so in the house right? The biggest! } \\
\text { Because the minors only study (E2). }\end{array}$ \\
\hline Ethical behaviour & $\begin{array}{l}\text { [We have importance in the market] because you will not get a lot of } \\
\text { unemployed family. The way unemployment is, right? (E4) }\end{array}$ \\
\hline Community work & Yes. I donate every month to the church. (E10) \\
\hline Unfair wages & $\begin{array}{l}\text { There are things I do not think are fair. It should be better. There are } \\
\text { things that I really get into because I think that the person give the } \\
\text { piece to me for the price and you really see that it can be a little bit } \\
\text { more and I complain a lot. (E3). }\end{array}$ \\
\hline Minority inclusion & $\begin{array}{l}\text { Yes, I would hire. There would be no problem [however they have no } \\
\text { disabled staff] (F1, F2, F3, F4 e F5). }\end{array}$ \\
\hline Gender & Not any, I do not have this prejudice (F3). \\
\hline $\begin{array}{l}\text { Marginalised } \\
\text { people inclusion }\end{array}$ & $\begin{array}{l}\text { No way, thank God [indicating that he has no problem hiring] (F3). } \\
\text { Oh, because I like helping people. I like to give opportunity, } \\
\text { sometimes people do the wrong things for lack of opportunity (F1). }\end{array}$ \\
\hline \multicolumn{2}{|l|}{ Health and safety } \\
\hline Work schedule & $\begin{array}{l}\text { Impressively from eight in the morning until six in the afternoon, from } \\
\text { Monday to Thursday. And from eight in the morning until five in the } \\
\text { afternoon on Friday. All of them! Do not overdo also leave early. } \\
\text { Facção is from seven thirty to four thirty. They make their schedules. } \\
\text { Because it's like it's a cooperative here. There in the interior of } \\
\text { Redenção, I do not know (E8). }\end{array}$ \\
\hline Working conditions & $\begin{array}{l}\text { I believe they are all well and good, right? My intention is to improve } \\
\text { every time. But at the moment I can not, because even today we had } \\
\text { a meeting and I was saying to them, "people, we're going to have to } \\
\text { improve on productivity, because lately I'm not even taking the light } \\
\text { off!" (F1). }\end{array}$ \\
\hline Awards & $\begin{array}{l}\text { When they are ... Produce more, there I ... I give an award, a little gift } \\
\text { (F1). }\end{array}$ \\
\hline \multicolumn{2}{|c|}{ Supplier Development } \\
\hline
\end{tabular}




\begin{tabular}{ll}
\hline \multicolumn{1}{c}{ Social Indicators } & \multicolumn{1}{c}{ Quotes } \\
\hline $\begin{array}{l}\text { Type of } \\
\text { Relationship }\end{array}$ & $\begin{array}{l}\text { They ask me, they ask me for a faster way to work. Yeah, they say } \\
\text { like this: "Dona Cleide, our piece is from here. But if you think you } \\
\text { have to change something in the piece, to get the production lighter, } \\
\text { give your opinion!" (F2). }\end{array}$ \\
\hline Trust & $\begin{array}{l}\text { Because so insecurity, I what I tell you ... I do not know if you have or } \\
\text { if they will still be with me [referring to companies] (F1). }\end{array}$ \\
\hline Supplier & $\begin{array}{l}\text { I never leave the house. Just... Just the Mira Mary, that the boy } \\
\text { comes... Because so, they are starting now and are with the same } \\
\text { insecurity that... (F1). }\end{array}$ \\
\hline Supplier selection & $\begin{array}{l}\text { No. Actually, it's that blind thing. But it's always in confidence right? } \\
\text { (F1). }\end{array}$ \\
\hline
\end{tabular}

Source: Own data (2017).

In a similar way to the formal group, when asked to this group about whether they had already heard about slavery work and child work in Fortaleza, all responded that they had never heard of it. For this group there is also ethical behavior, in the economic development requirement, since they help increase the quality of life of the society in the generation of employment and income, even if there is no total formality in its activities. In relation to philanthropic actions and community work, most donations were identified, with the exception of Forn1, who reported participating in a social project of inclusion of the lesser apprentice, also referring that it is a law that exists.

Regarding the inclusion of disabled people, all said they did not have employees with disabilities in their companies. In relation to the hiring of other minorities, all of this group responded not to have problem of hiring people of other religions, races or ethnic groups. Again, it is worth stressing the need to reflect on the intention and action of hiring. For gender, they stated that they treated equal men and women, both in hiring, in relation to wages, and in the development of activities. In the inclusion of marginalized people, only F1 spoke to hire. During the interviews this topic has always proved controversial, aspect that needs to be more debated.

For the Health and Safety category, in relation to the working schedule indicator, all work in hours to fulfill the workload of 44 hours a week, except F3, which says work until late at night for what they like. For the indicator working conditions everyone in this group says they offer good working conditions to their employees. Regarding awards only F1 pays it to its seamstresses, depending on the production of the pieces. These aspects may be related to the idea of decent work presented by Vargas (2016). According to the author, even within the context of informal work this is an element sought by companies in the market.

For the Suppliers Development category, in relation to the indicator types of relationships, all of this group maintains long-term relationships with its suppliers and customers. However, they do not and do not receive any kind of training from their customers and suppliers. As for the trust indicator, this group had lower levels of trust in relation to facções and companies. For the respondents of the informal group, there was no identification of supplier assessment, and identification of none that makes selection of the supplier for social risk assessment. In general, some specificities are perceived for this group of respondents in relation to what was identified in the other group of responses. This fact suggests that there is a need to identify if formality and social indicators influence each other. 


\section{Discussions}

The results identified represent as social indicators have been developed in the sector. However, it is necessary to discuss each of the groups. Thus, regarding social responsibility, no clear difference was identified between the formal and informal groups, which suggests that this dimension is not influenced by formalization. Companies that wish to perform social practices do so according to their demands, that is, social responsibility is a practice that depends on the individual dynamics of each organization according to their goals and deliveries in society. However, in the case studied the indicators: community work, minorities inclusion and marginalized people inclusion, were negative in practically all companies, which shows low adherence to the elements of social responsibility.

In the health and safety dimension, there is a general alignment between the groups when it comes to working schedule indicators and working conditions in companies, but it is worth noting that when talking about employee awards, three informal companies do not perform any kind of awards. In this case, it is possible reflect on the influence of this informality in the search for better aspects of health and safety. Thus, in this case the formality generates greater involvement with social indicators, mainly due to its external influence from the government. For Mendes \& Campos (2004), informal workers belonging to the upstream supply chain (suppliers, service providers, etc.) and downstream (distributors, sellers, and consumers) should be considered as strategic partners, especially in the most critical areas such as health and safety. This fact demonstrates the need for a greater look at issues of how to deal with organizational formats in a supply chain.

Regarding the supplier development dimension, all respondents seek long-term relationships, which is conducive to creating more stable interactions. In relation to proximity to its suppliers, only two companies E12 and E13 spoke to have proximity to their suppliers, company E12 said, "their facções have become family". Regarding trust, all companies say they trust suppliers, but the opposite is not entirely true, especially because according to some factions, sometimes companies do not play their paying by the deadline. This is a very important aspect for the development of social practices. This fact shows that informality still proves detrimental to the formal, especially when it comes to seeking alternatives to collect their demands.

Regarding the supplier assessment, none of the companies or suppliers does this practice. This shows that there is little appreciation of the other actor in the supply chain studied. What requires greater involvement is in relation to social, environmental or economic. With the information identified in this research, it is noticed that although some companies have a certain involvement with social indicators individually, but when speaking in the context of supply chain this is still far from being realized. To have greater adherence to sustainability-oriented social indicators, companies - mostly SMEs - need to maintain their legal responsibility in the economic context and seek to develop other activities that increase their impact on society, which directly affects the involvement of members in this process.

As it can be observed, some companies are formalized, maintaining in their workforce informal employees such as E3, E4, E5, E8 and E10, but companies do not realize that such a situation can constitute informal work (Vargas, 2016), which undermines the concept of formality required by legal requirements. Despite this, Vargas (2016) indicates that even in an informal economy, decent work is something necessary, which is observed in this research. Different from facções, because for Castel (1998), this informality and precariousness is a central process governed by the 
new technological and economic requirements of the evolution of modern capitalism (Castel, 1998). This reflection is necessary to intensify the debate about supply chain sustainability, since as was observed in the present research, there is some influence of the formal practice in the insertion of social indicators.

Although companies, suppliers and facções studied have similar social indicators, those companies and factions that do not sign the wallet work of employees have difficulties in inserting social indicators in the supply chain in relation to working conditions and compliance with working schedule according to legislation. By negatively impacting the health and safety category on some indicators, with the inclusion of responsibilities and standards. With this, it is perceived that the research presupposition is effective, which the formality influences the insertion of the social. This research corroborate with Cirino (2014), when he concluded that the proposals of flexibilization of labor rights and the precariousness of labor relations are obstacles to the implementation of sustainable practices in the labor environment and increase the problems of health, well-being and safety at work. This is not the case for companies that have formal workers inside their premises.

In relation to the facções, corroborating with the research of Araújo \& Amorim (2016), those who work for the Fashion Center are totally subordinated to the conditions, deadlines, forms of payment imposed by the companies for which they manufacture, but in a precarious working relationship established informally to escape regulation and legal burdens. Therefore, in order to respond to the research objective, it can be seen that formalization has a preponderant role both in the dynamics of companies' activities in the market and in the insertion of social practices in the supply chain. In general, this research contributes to the SCS debate, especially in the social context, because it brings up the need to discuss elements that surround the social practices that are constantly sought in the literature, but still in an incipient way while results.

\section{Conclusions}

From the data presented on the social indicators implemented by members of the supply chain, it was observed that companies do not perform any type of inspection or audit to mitigate social risks of their suppliers. For the indicators slavery work and child work, all members of the chain were negative, which is relevant mainly in the context of garment that has been widely criticized. All of the indicators presented ethical behavior, for the economic development requirement, and companies take some actions to training and help suppliers, but the developments of these actions do not deal with social issues, which demonstrates that trust is not always was present in relationships.

From these results there are two main contributions: (1) to the theory by proposing a classification of social indicators in the supply chain becomes relevant. In addition, conducting research from the perspective of formalization demonstrates a breakthrough in the social debate, as there is no consensus on how to deal with this theme that is constant in the Brazilian economy; (2) for the practice, for drawing the attention of the actors involved to the informal relations of work in the popular garment sector. Thus, responsible agencies can intensify the surveillance of informality throughout the supply chain. Something that should not be observed as only punitive, but in the pursuit of actions that contribute to a decent work and within the legal requirements even whether informal. 
Thus, practices of analysis and intervention in the supply chains from the point of view of the public power can bring alternatives to face the vulnerabilities, risks, social damages, increasingly prominent and problematic in the Brazilian context. It is understood as research limitation the use of a relation still not elaborated in the literature, which limits, however does not invalidate the findings. The research assumption was proved, but it would be necessary to deepen the relationships analyzed. Since only first tier suppliers in the garment chain were interviewed, it would have been interesting to interview the industries that produce everything from fibers to yarns and fabrics.

Thus, future research should be developed for a better understanding, what can be considered as informal work, and what can still be considered as illegal work, still hazy themes in the literature. Moreover, this perspective can be transferred to other sectors and contexts, both through other qualitative research techniques, and through surveys that may facilitate the demonstration of the formalization as moderator or mediator of relations in supply chains in relation to social indicators toward sustainability.

\section{References}

Abdala, E. C., \& Barbieri, J. C. (2014). Determinants of Sustainable Supply Chain: an analysis of mensuration models of pressures and socio-environmental practices. Journal of Operations and Supply Chain Management, 7(2), 110-122. http://dx.doi.org/10.12660/joscmv7n2p110-123.

Almeida, F. (2002). O bom negócio da sustentabilidade (1. ed.). Rio de Janeiro: Nova Fronteira.

Alves, A. P. F., \& Silva, M. E. (2017). Reflexões empíricas sobre a dimensão social da Sustentabilidade em Cadeias de Suprimento: o que precisa mudar? Revista de Gestão Ambiental e Sustentabilidade, 6(1), 13-25. http://dx.doi.org/10.5585/geas.v6i1.529.

Andersen, M., \& Skjoett-Larsen, T. (2009). Corporate social responsibility in global supply chains. Supply Chain Management, 14(2), 75-86. http://dx.doi.org/10.1108/13598540910941948.

Araújo, A., \& Amorim, E. R. A. (2016). Redes de subcontratação e trabalho a domicílio na indústria de confecção: um estudo na região de Campinas. Cadernos Pagu, 17-18, 267310.

Ashby, A., Leat, M., \& Hudson-Smith, M. (2012). Making connections: a review of supply chain management and sustainability literature. Supply Chain Management, 17(5), 497-516. http://dx.doi.org/10.1108/13598541211258573.

Associação Brasileira da Indústria Têxtil e de Confecção - ABIT. (2017). Indústria têxtil e de confecção brasileira: cenários, desafios, perspectivas, agenda de competitividade da indústria têxtil e de confecção brasileira: 2015 a 2018. São Paulo: ABIT. Retrieved in 2017, June 14, from http://www.abit.org.br/conteudo/links/Poder_moda-cartilhabx.pdf

Bardin, L. (2011). Análise de conteúdo. São Paulo: Edições 70.

Campos, S. A. P., Alves, A. P. F., \& Pedrozo, E. (2014). Responsabilidade social na cadeia de suprimento: construindo parcerias colaborativas entre organizações. In Anais do XVII SIMPOI. São Paulo: ABEPRO.

Carter, C. R., \& Rogers, D. S. (2008). A framework of sustainable supply chain management: moving toward new theory. International Journal of Physical Distribution \& Logistics Management, 38(5), 360-387.

Carvalho, A. P., \& Barbieri, J. C. (2013). Inovações socioambientais em cadeias de suprimento: um estudo de caso sobre o papel da empresa focal. Revista de Administração e Inovação, 10(1), 232-256. http://dx.doi.org/10.5773/rai.v1i1.1109. 
Castel, R. (1998). As metamorfoses da questão social: uma crônica do salário (5. ed.). Petrópolis: Vozes.

Chen, C. C., Shih, H. S., Wu, K. S., \& Shyur, H. J. (2009). Using ANP for the selection of green supply chain management strategies. In Proceedings of the 10th International Symposium on the Analytic Hierarchy Process (pp. 1-15). Pittsburgh: ISAHP.

Ciliberti, F., Pontrandolfo, P., \& Scozzi, B. (2008). B. Investigating corporate social responsibility in supply chains: a SME perspective. Journal of Cleaner Production, 16(15), 1579-1588. http://dx.doi.org/10.1016/j.jclepro.2008.04.016.

Cirino, S. M. (2014). Sustentabilidade no meio ambiente de trabalho: um novo paradigma para a valorização do trabalho humano. Revista Eletrônica Direito e Sustentabilidade, 3(28), 85108.

Claro, P. B. O., \& Claro, D. P. (2004). Desenvolvimento de indicadores para monitoramento da sustentabilidade: o caso do café orgânico. Revista de Administração da Universidade de São Paulo, 39(1), 18-29.

Claro, P. B. O., Claro, D. P., \& Amâncio, R. (2008). Entendendo o conceito de sustentabilidade nas organizações. Revista ADM, 43(4), 289-300.

Dicken, P. (2007). Global shift: mapping the changing contours of the world economy. London: SAGE Publications.

Gaskell, G. (2002). Pesquisa qualitativa com texto, imagem e som: um manual prático. In M. Bauer \& G. Gaskell (Eds.), Entrevistas individuais e grupais (2. ed., pp. 64-89). Petrópolis: Vozes.

Glavič, P., \& Lukman, R. (2007). Review of sustainability terms and their definitions. Journal of Cleaner Production, 15(18), 1875-1885. http://dx.doi.org/10.1016/j.jclepro.2006.12.006.

Gold, S. (2016). Sustainable supply chain management research in Brazil. In M. E. Silva \& L. F. M. Nascimento (Eds.), Sustentabilidade em cadeias de suprimento: entre teoria e prática. Porto Alegre: ePUB.

Goldenberg, M. (2004). A arte de pesquisar: como fazer pesquisa qualitativa em Ciências Sociais (8. ed). Rio de Janeiro: Record.

Guerra, I. C. (2006). Pesquisa qualitativa e análise de conteúdo: sentidos e formas de uso. Cascais: Edição Princípia.

Hamann, R., Agbazue, T., Kapelus, P., \& Hein, A. (2005). Universalizing corporate social responsibility? South African challenges to the International Organization for Standardization's new social responsibility standard. Business and Society Review, 110(1), 1-19. http://dx.doi.org/10.1111/j.0045-3609.2005.00001.x.

Heleno, E. (2013). Configurações do trabalho a domicílio nas confecções de roupa de jeans no município de Toritama (Tese de doutorado). Universidade Federal da Paraíba, João Pessoa.

Hirata, H., \& Préteceille, E. (2002). Trabalho, exclusão e precarização socioeconômica: o debate das ciências sociais na França. Caderno $C R H, 37,47-80$.

Instituto Brasileiro de Geografia e Estatística - IBGE. (2016). Estimativa da população 2016. Rio de Janeiro: IBGE. Retrieved in 2018, May 9, from http://www.cidades.ibge.gov.br/comparamun/compara.php?lang=\&coduf $=0 \&$ idtema $=130 \& \mathrm{c}$

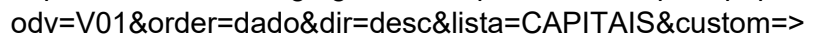

Kanji, G. K., \& Chopra, P. K. (2010). Corporate social responsibility in a global economy. Total Quality Management, 21(2), 119-143. http://dx.doi.org/10.1080/14783360903549808.

Köksal, D., Strahle, J., Muller, M., \& Freise, M. (2017). Social sustainable supply chain management in the textile and apparel industry: a literature review. Sustainability, 9(1), 100. http://dx.doi.org/10.3390/su9010100. 
Leão, L. H. C., \& Vasconcellos, L. C. F. (2015). Cadeias produtivas e a vigilância em saúde, trabalho e ambiente. Saúde e Sociedade, 24(4), 1232-1243. http://dx.doi.org/10.1590/S0104-12902015136460.

Lepoutre, J., \& Heene, A. (2006). Investigating the impact of firm size on small business social responsibility: a critical review. Journal of Business Ethics, 67(3), 257-273. http://dx.doi.org/10.1007/s10551-006-9183-5.

Lima, J. C. (1999). Novas formas, velhos conteúdos: diversidade produtiva e emprego precário na indústria do vestuário. Revista Política e Trabalho, 15, 121-139.

Markley, M. J., \& Davis, L. (2007). Exploring future competitive advantage through sustainable supply chains. International Journal of Physical Distribution \& Logistics Management, 37(9), 763-774. http://dx.doi.org/10.1108/09600030710840859.

Meixell, M. J., \& Luoma, P. (2015). Stakeholder pressure in sustainable supply chain management. International Journal of Physical Distribution \& Logistics Management, 45(1/2), 69-89. http://dx.doi.org/10.1108/IJPDLM-05-2013-0155.

Mendes, R., \& Campos, A. C. C. (2004). Saúde e segurança no trabalho informal: desafios e oportunidades para a indústria brasileira. Revista Brasileira de Medicina do Trabalho, 2(3), 209-223.

Neutzling, D. M. (2016). Sustentabilidade em cadeias de suprimento sob o olhar da estratégia. In M. E. Silva \& L. F. M. Nascimento (Eds.), Sustentabilidade em cadeias de suprimento: entre teoria e prática. Porto Alegre: ePUB.

Neves, M. A., \& Pedrosa, C. M. (2007). Gênero, flexibilidade e precarização: o trabalho a domicílio na indústria de confecções. Sociedade e Estado, 22(1), 11-34. http://dx.doi.org/10.1590/S0102-69922007000100002.

Pagell, M., \& Wu, Z. (2009). Building a more complete theory of sustainable supply chain management using case studies of 10 exemplars. The Journal of Supply Chain Management, 45(2), 37-56. http://dx.doi.org/10.1111/j.1745-493X.2009.03162.x.

Samaranayake, P. (2005). A conceptual framework for supply chain management: a structural integration. Supply Chain Management, 10(1), 47-59. http://dx.doi.org/10.1108/13598540510578379.

Seuring, S. (2013). A review of modelling approaches for sustainable supply chain management. Decision Support Systems, 54(4), 1513-1520. http://dx.doi.org/10.1016/j.dss.2012.05.053.

Seuring, S., \& Müller, M. (2008). From a literature review to a conceptual framework for sustainable supply chain management. Journal of Cleaner Production, 16(15), 1699-1710. http://dx.doi.org/10.1016/j.jclepro.2008.04.020.

Seuring, S., Sarkis, J., Müller, M., \& Rao, P. (2008). Sustainability and supply chain management: an introduction to the special issue. Journal of Cleaner Production, 16(15), 1545-1551. http://dx.doi.org/10.1016/j.jclepro.2008.02.002.

Silva, M. E., \& Nascimento, L. F. (2015). Emphasizing social issues toward sustainable supply chain: a Brazilian perspective. Independent Journal of Management \& Production, 6(2), 478-494. http://dx.doi.org/10.14807/ijmp.v6i2.288.

Silva, M. E., \& Nascimento, L. F. (2016). (Re) pensando a intersecção entre sustentabilidade e cadeia de suprimento. Revista Espacios, 37, 4.

Silva, M. E., Alves, A. P. F., \& Barcellos, M. D. (2016). "Sustainable Beef": práticas para a sustentabilidade na cadeia da carne bovina gaúcha. Desenvolvimento em Questão, 14(35), 274-306. http://dx.doi.org/10.21527/2237-6453.2016.35.274-306.

Vachon, S., \& Klassen, R. (2008). Environmental management and manufacturing performance: the role of collaboration in the supply chain. International Journal of Production Economics, 111(2), 299-315. http://dx.doi.org/10.1016/j.ijpe.2006.11.030. 
Van Marrewijk, M. (2003). Concepts and definitions of CSR and corporate sustainability: between agency and communion. Journal of Business Ethics, 44(2), 95-105. http://dx.doi.org/10.1023/A:1023331212247.

Vargas, J. (2016). O mundo, o Brasil e a informalidade no trabalho: uma abordagem conceitual. Revista Capital Científico Eletrônica, 14, 3.

World Commission on Environment and Development - WCED. (1987). Our common future. Ottawa: WCED.

Yawar, S. A., \& Seuring, S. (2017). Management of social issues in supply chains: a literature review exploring social issues, actions and performance outcomes. Journal of Business Ethics, 141(3), 621-643. http://dx.doi.org/10.1007/s10551-015-2719-9.

Yin, R. (2015). Estudo de caso: planejamento e métodos (5. ed). Porto Alegre: Bookman.

Zacharia, Z. G., Nix, N. W., \& Lusch, R. F. (2011). Capabilities that enhance outcomes of an episodic supply chain collaboration. Journal of Operations Management, 29(6), 591-603. http://dx.doi.org/10.1016/j.jom.2011.02.001. 


\section{Appendix A. Interview Script.}

About the company

1. Can you please provide information about how did your company start its activities?

2. What is your role within the company? In addition to manager, do you play any other position?

3. How long does the company operate in the popular market?

4. How many employees do you have in the company? Are they all formal?

5 . Does the company only manufacture its products for the popular market?

Social indicators

6. Several cases in the garment industry around the world have been denounced for having slave/child/illegal work, have you heard anything about it here in Fortaleza?

7. Do you think your company is important to the industry?

8. Does the company practice any kind of donation?

9. Does the company have any program for hiring minorities or marginalized people? Ex. - employee with some disability, inmates, very poor people. If so, how do you hire it?

10. Do you think fair value is paid to employees and outsourced? Why?

11. Does the company grant any additional benefit to its employees? Premium, health plan etc.

12. What are your employees' work schedules like?

13. Does the company offer good working conditions to its employees?

14. Are the company and its employees associated with any type of union?

15. Does the company often maintain long-term and close relationships with its suppliers and outsourced?

16. What is the level of trust the company has with its supplier and outsourced?

17. Is there any part of the production process that is outsourced? If so, are the people who provide this type of service all formal? 